\title{
Kentsel Tarihi Çevrelerde Sokak Sağlıklaştırma Çalışmaları: Bartın Örneği
}

Street Rehabilitation in Urban Historical Environments: The of Case Bartın

\author{
Deniz ÇELIIK ${ }^{* 1, a}$, Dilara DEMIRTAŞ ${ }^{1, b}$ \\ ${ }^{I}$ Barın Üniversitesi, MYO, Park ve Bahçe Bitkileri Bölümü, 74100, Bartın \\ ${ }^{2}$ Bartın Üniversitesi, Fen Bilimleri Enstitüsü, Peyzaj Mimarllğ̆ Anabilim Dall, 74100, Bartın
}

\begin{tabular}{lll}
\hline •Geliş tarihi / Received: 21.01.2019 • Düzeltilerek geliş tarihi / Received in revised form: 28.05.2019 • Kabul tarihi / Accepted: 21.06.2019 \\
\hline
\end{tabular}

\begin{abstract}
Öz
Tarihi çevreler bulunduğu bölgenin gelenek ve göreneklerini, yaşam tarzını, sosyal yapısını, ekonomik durumunu, kültürünü, teknolojisini, mimarisini, vb. özelliklerini bugüne taşıyan kültürel varlıklardır. Geçmiş ile günümüz arasında köprü kuran tarihi belge niteliğindedirler. Fakat zaman içinde doğal ya da insan kaynaklı nedenlerden dolayı tahribat, eskime, yıpranma gibi sorunlarla karşı karşıya kalmaktadırlar. Bu nedenle korunmaları, iyileştirilmeleri gerekmektedir. Koruma kapsamında yapıların restorasyonu, restitüsyonu, sıhhileştirilmesi ya da sokak sağlıklaştırma çalışmaları yapılmaktadır. Günümüzde sadece fiziki mekânı değil sosyo kültürel yapıyı da içine alan bütüncül koruma anlayışı ön plana çıkmaktadır. Aynı zamanda tarihi çevreleri koruma ve yaşatma faaliyetleri ile çekim noktaları, cazibe merkezleri de oluşturulabilmektedir. Bu bağlamda araştırmanın amacı, Bartın kenti Hükümet Caddesi ve etkileşim içinde olduğu tarihi kent merkezinde koruma kullanma dengesi gözeterek, kentsel peyzaj odaklı sokak sağlıklaştırma çalışmalarında uyulması gereken ilkeleri belirlemektir. Araştırma literatür taraması, alan analizleri, verilerin değerlendirilmesi, sonuç ve öneriler olmak üzere dört aşamada gerçekleştirilmiştir. Araştırma sonucunda, alanının Bartın kent kimliğini kısmen yansıttığı, eskime, yıpranma gibi fiziksel sorunlar yaşandığı saptanmıştır. Hükümet Caddesi ve etkileşim alanı özelinde kentsel peyzaj odaklı sokak sağlıklaştırma projelerinde planlama, tasarım, uygulama bağlamında ölçütler geliştirilmiş̧ir. Sonuç olarak, tarihi çevreleri koruma ve geliştirmeye yönelik hedefler/politikalar imar planları, koruma amaçlı imar planları, kalkınma planları, turizm planları ile birlikte düşünülmelidir. Bu kararları benimseyecek politik irade olmalıdır. Ayrıca yerel halkın, yatırımcıların, üniversitenin, kanaat önderlerinin birlikte hareket etmesi ve parasal araçların belirtilmesi önem taşımaktadır.
\end{abstract}

Anahtar kelimeler: Kentsel peyzaj, Koruma, Kimlik, Peyzaj tasarımı, Tarihi çevre

\begin{abstract}
The historic environments are the cultural beings which have the traditions and customs of the region, life style, social structure, economical status, culture, technology, architecture, etc. They are the historical documents that bridge the past and the present. However, due to natural or man-made reasons, they have faced some problems such as destruction. Therefore, they must be protected and rehabilited. The restoration, restitution, rehabilitation or street rehabilitation works are carried out within the scope of the conservation. Today, holistic protection concept including not only physical space, but also socio-cultural structure, comes to the fore. At the same time, it is possible to create attraction points and attraction centers with the protection and survival activities of historic environments. In this context, the aim of the study is to determine the principles to be followed in urban landscape-oriented street rehabilitation studies by considering the balance of use and protection Hukumet Avenue in Bartin city and the historical city center where it interacts. The research has created with four stages: literature review, field analysis, evaluation of data, results and recommendations. As a result of the research, principles have been developed in the context of planning, design and implementation in the urban landscape-oriented street rehabilitation projects in the Hukumet Avenue and interaction area. As a result, targets / policies for conservation and development of historic environments should be considered together with development plans, development plans for conservation, and tourism plans. There must be a political will to adopt these decisions. It is also important that local people, investors, universities and opinion leaders act together and specify financial instruments.
\end{abstract}

Keywords: Urban landscape, Conservation, Identity, Landscape design, Historical environment

\footnotetext{
*a Deniz ÇELIK; dcelik@bartin.edu.tr; Tel: (0532) 731 81 89; orcid.org/0000-0003-4230-2157

${ }^{\mathrm{b}}$ orcid.org/0000-0001-6171-7599
} 


\section{Giriş}

Tarihi çevreler geçmişin izlerini günümüze taşıyan mekanlardır. Geleneksel yaşam biçimleri, kültürü, mimari özellikleri ile şekillenmiş bu çevrelerde konut, ticaret, dini yapılar gibi farklı kullanımlar bir arada ve birbirleriyle etkileşim içinde bulunmaktadır. İnsan ölçeğinde tasarlanmış sokakları, meydanları, sivil mimari yapıları ve anıtsal kültür varlıkları ile bu mekanlar günümüzün açık hava müzeleri niteliğindedir (Ahunbay, 2004). Bunun yanı sıra tarihi çevreler de yer alan kültür varlıkları geçmiş yaşam kültürünü, ulaşılan teknolojiyi günümüze taşıyan tarihi belge niteliğindedir. $\mathrm{Bu}$ kültür varlıkları birçok değere sahiptir. Bu değerler tarihsellik, mitolojik, artistik, özgünlük, enderlik, homojenlik, işlevsellik ve eğitim değeri olarak özetlenebilir (Madran, Özgönül, 2005).

Tarihi mekanlar ölçeğe bağlı olarak üç grup altında toplanabilir. Bunlar, tarihi çevre, tarihi kent ve tarihi bölgelerdir. Tarihi çevre doku özelliği gösterir, bir veya birkaç sokaktan meydana gelmektedir. Tarihsel geçmişi, mimari özellikleri ile bir bütünlük gösterir. Antalya Kaleiçi, Bursa Hisar Mahallesi örnek olarak verilebilir. Tarihî kent, gerek tarihsel gerekse mimari özellikleri ile bütünlük gösteren dokuların bir araya gelmesiyle oluşan Prag, Venedik gibi kentsel yerleşimlerdir. Tarihî bölge ise tarihsel geçmişi ve mimari özellikleri bakımından bütünlük gösteren birden fazla kentin bir araya gelmesiyle oluşan bölgelerdir. Orta Asya, Mezopotamya gibi örnekler mevcuttur (Özyaba, 1999).

Tarihi kentler ve tarihi kent merkezlerinde doğal ve yapay çevreler yer almaktadır. Bu çevreler sanayileşmeyle ivme kazanan kentsel gelişmenin etkisi altında kalarak fiziksel aşınma ve tahrip olma tehdidi altındadır. Bu nedenle tarihi kent ve kentsel alanların gelişmesi ve çağdaş yaşam koşullarına uyumu için muhafazası, korunması ve restorasyonu gereklidir (URL-1, 2019). Ayrica, tarihi çevrelerde iklim, deprem, yangın, ekonomideki değişim, kente göç gibi doğal ya da insan etmenli nedenlerden dolay1 bozulma veya tahribatlar da olabilmektedir. Zaman içinde mekânsal ölçekte, nitelikte ve kimlikte değişimler başlayabilmektedir (Anonim, 2009). Bununla birlikte bu çevreler teknolojik gelişmeler, toplumsal değişim, küreselleşme gibi etkiler nedeniyle de birtakım sorunlarla kaşı karşıya kalabilmektedir. Örneğin altyapı eksikliği, fiziksel eskime gibi nedenlerden dolayı yaşayan kişi sayısında azalma söz konusu olabilmektedir
(Smith, 2002). Bu gibi nedenlerden dolayı tarihi çevrelerin korunması gerekmektedir. Tarihi çevrelerde yapılan koruma çalışmalarının amacı kent peyzajını, kimliğini, geleneksel yerleşim dokusunu korumak, fiziksel ortamda yaşam kalitesini artırmak ve kullanım sürekliliğini sağlamak olarak özetlenebilir (Çelik ve Yazgan, 2007). Korumayla birlikte kentlerin ekonomik kalkınmasına da katkıda bulunulabilecektir. Korumada hem fiziki, hem de kültürel, sosyoekonomik, toplumsal koruma sağlanmış, doğal ve kültürel kaynakların günün koşullarına göre kullanılabilirliği ve sürdürülebilirliği gerçekleşmiş olacaktır (UNESCO, 2013).

Tarihi çevrelerin korunması çalışmalarında yerel toplumla birlikte çalışmak, onların sosy-kültürel yapısı ve düşüncelerini almak bu çevrelerin şekillenmesinde önem taşımaktadır (Elnokaly ve Elseragy, 2013). Böylece, kentsel kimliğin, estetiğin korunması, geçmiş, günümüz ve gelecek arasında bir bağın kurulması mümkün olabilecektir (Çelik, Açıksöz 2008; Kiper, 2008). Yap1 ölçeğinde restorasyon işlemleri ile koruma sağlanırken, kentsel/bütüncül korumada yapısal, işlevsel, simgesel ve toplumsal boyutları birlikte ele alan koruma gündeme gelmektedir (Kuban, 2000). Aynı zamanda tarihi çevreleri koruyarak yap1 stoku durumundaki geleneksel yapıların kullanılabilirliğinin artmasına, kente yeni çekim noktalarının kazandırılmasına, yerele ekonomik katkıda bulunulmasına imkan verilebilecektir (Smith, 2002; Çetin ve Sönmez, 2014).

Genel anlamda tarihi kent korumasını iki boyutta ele almak mümkündür. Birincisi mimari korumadır ve arkeoloji, mimari sitil, yapım materyali ve tekniklerini kapsar. İkincisi kent korumasidır. Bu da kenttin morfolojik ve estetik değişimini korumaktır (Rodwell, 2007). Tarihi çevrelerin kullanılması ve korunarak gelecek kuşaklara aktarılması hedeflenirken mimari koruma kapsaminda tarihi yapılar restore edilmektedir. Ayrica tarihi yapılara uygulanan farklı koruma yöntemleri de söz konusudur. Bunlar, sağlamlaştırma, bütünleme, yenileme, yeniden yapma, temizleme ve taşımadır. Tarihi çevre korumanın temel amacı tarihi yerleşmeyi yok olmaktan kurtarmak, kültür mirasını günümüz yaşamıyla bütünleştirmektir (Ahunbay, 2004). Tarihi çevre koruma yöntemlerinden biri de sokak sağlıklaştırma çalışmalarıdır. Sokak sağlıklaştırma ile fiziksel, sosyal ve kültürel koruma/iyileştirme ile birlikte tarihi bir belge niteliğinde olan tarihi yapıların belgelenmesi, rölöve, restitüsyon ve restorasyonu da mümkün olabilmektedir (URL-2, 2019; Ünver, 2017). 
Sokak sağlıklaştırma projeleri tarihi yapıların korunmasını, alanda yaşayan kişilerin çağdaş yaşam konforundan yararlanmasını, kent estetiğinin artırılmasını ve yerel halkta koruma bilinç düzeyinin artmasını kolaylaştırmaktadır. Ulusal ve uluslararası boyutta sokak sağllklaştırmaya yönelik birçok proje ve uygulama alanları söz konusudur. Örneğin, İzmir Kemeraltı Sokak Sağlıklaştırma çalışmalarında yerel yönetim bölge halkıyla birlikte hareket etmiş, alana yönelik planlama ve uygulama süreçlerinde uzlaşma ve işbirliği sağlanmıştır. Dolayısı ile bütünleşik koruma yani fiziksel ve sosyal yapıyı korumakta mümkün olmuştur (Altınörs Çırak, 2017). Eskişehir Tarihi Odunpazarı Bölgesi'nde Sokak Sağlıklaştırma Projeleri ile tarihi yapıların restorasyonu yapılarak, daha sağlam, sağlıklı ve estetik olmaları sağlanmıştır (URL-3, 2019). Beypazarı Sokak sağlıklaştırma projesi kapsamında tarihi çarşı içinde yer alan yapıların röleve ve retitüsyon projeleri hazırlanıp, restorasyonları yapılmıştır. Tarihi sokak doku bütünlüğünü koruyacak şekilde yaşatılmaya çalışılmıştır (URL-4, 2019). Uluslararası alanda ise sokak sağlıklaştırma çalışması kapsamında Dünyanın en küçük şehri olarak bilinen Belçika'nın Durbuy şehrinde organik yapıdaki sokaklar sadece yayaların kullanacağı şekilde planlanmış ve tarihi doku mevcut durumuyla korunmuştur. Fransa'daki Saint-Paul De Vence kasabasında yapılan koruma çalışmaları sırasında tarihi binaların bir kısmı ticari işletme olarak değerlendirilmiş ve tarihi yapılarla uyum sağlayan kentsel donatı elemanları kullanılarak kentsel kimlik korunmuştur. İtalya'da bulunan Siena kentinde Ortaçağ mimarisini yansıtan taş binaların yer aldığ merkezinde tarihi doku hem korunmuş hem de turistik cazibe merkezi haline getirilmiştir (Çelimli, 2016).

$\mathrm{Bu}$ bağlamda araştırmada nüfus artışı, hızlı kentleşme, yapı endüstrisindeki teknolojik gelişim ve fiziksel eskime gibi nedenlerden dolay değişim ve dönüşümün yaşandığı Bartın kentindeki Hükümet Caddesi ve etkileşim içinde olduğu tarihi kent merkezinde kentsel peyzaj odaklı sokak sağliklaştırma plan ve projelerine yönelik ölçütlerin belirlenmesi amaçlanmıştır. $\mathrm{Bu}$ kapsamda "sokak sağlıklaştırma plan ve projelerine yönelik ölçütler nelerdir? "Tarihi çevrede sokak sağlıklaştırma çalışmalarının yerel halk için önemi nedir? Neler yapılabilir?" sorularına cevaplar aranmıştır.

\section{Materyal ve Yöntem}

Araştırmanın ana materyalini Bartın kentinde bulunan Hükümet Caddesi ve etkileşim içinde olduğu tarihi kent merkezi oluşturmaktadır. Bu alanın seçilme nedeni Koruma Amaçlı İmar Plan sınırı içinde yer alması, alanda tescilli binaların bulunmas1, yerel halk tarafindan yoğun olarak kullanılması, sosyokültürel amaçlı aktiviteler için tercih ediliyor olması, ulaşımın kolay olmasıdır. Ayrıca Bartın Belediyesi İmar ve Şehircilik Müdürlüğünden elde edilen $1 / 1000$ ölçekli Koruma Amaçlı İmar Planı ve raporu, arazi çalışması sırasında elde edilen fotoğraflar ile tarihi kent dokusuna ait eski fotoğraflar da materyal olarak kullanılmıştır. Çalışma alanı sınırlarını Karakaş Caddesi, Yukarı Çarşı Caddesi ve 636. Sokak (eski Rüştiye Sokak) oluşturmaktadır. Tarihi kent merkezinin ana arteri ise Hükümet Caddesidir (Şekil 1).

Araştırmanın yöntemi verilerin elde edilmesi, alan analizleri, değerlendirme, sonuç ve öneriler olmak üzere 4 aşamada gerçekleştirilmiştir. Birinci aşamada ulusal ve uluslararası literatür taraması yapılarak, konuya ve alana ilişkin veriler elde edilmiştir. Araştırma konusu ile ilgili kurum ve kuruluşlardaki kişilerle görüşülerek gerekli olan yazilı veriler, haritalar ve raporlar elde edilmiştir. İkinci aşamada; alan analizleri, gözlem ve fotoğraf çekimleri yapılarak mevcut durum saptanmıştır. Bartın Kentine ait 1/1000 ölçekli koruma amaçlı imar planı ile arazideki mevcut durum karşlaştırılarak tarihi dokunun mekansal özellikleri paftalara işlenmiştir. Bu kapsamda, mevcut kullanımlar, kat yükseklikleri, tescilli yapılar, ulaşım sistemi ve odak noktaları ile alanın etkileşim içinde olduğu açı yeşil alanlar belirlenmiş, Auto Cad 2011 programı kullanılarak haritalar oluşturulmuştur. Üçüncü aşamada, elde edilen veriler değerlendirilmiştir. Dördüncü aşamada ise ulaşılan sonuçlar verilerek, kentsel peyzaj odaklı sokak sağliklaştırma plan ve projeleri kapsamında Hükümet Caddesi ve yakın çevresinde yer alan sokak dokusuna, yapı cephelerine, kent mobilyalarına ve açık-yeşil alanlara yönelik ölçütler belirlenmiştir.

\section{Araştırma Bulguları}

\subsection{Bartın Kentine İlişkin Bulgular}

Bartın İli Batı Karadeniz bölgesinde, $41^{\circ} 37^{\prime}$ kuzey enlemi ile $32^{\circ} 22^{\prime}$ doğu boylamı arasında yer almaktadır. 
Yüzölçümü 2143 km2, ortalama yükselti 25 m'dir (Anonim, 2008). Bartın İli Bartın Irmağını oluşturan Kocaçay ve Kocanaz Çaylarının oluşturduğu ova üzerine kurulmuştur (Bartın Belediyesi, 2014). Bartın sınırları içinde Sesamos (Amasra), Kromna (Kurucaşile) ve Erythinoi (Çakraz) gibi önemli antik kentler yer almaktadır. Ekonomik yapının temel bileşenleri madencilik, sanayi, tarım, ticaret, turizm ve ormanciliktır. Geleneksel el sanatları içinde tel kırma, ahşap oymacılığ 1 , gemi yapımcılığ (Anonim,2007). 2018 y1lı merkez nüfusu 155.016 kişidir (URL-5, 2019). Bartın Kentine ait ilk imar planı 1957 yılında yapılmıştır. 1957 yılından sonra ise nüfus artışı, araç ve yaya trafiğinin yoğunlaşması gibi nedenlerden dolayı 1970, 19801983 yılları arasında farklı imar planları yapılmış ve günümüze kadar mevcut imar planları üzerinde revizyonlar gerçekleştirilmiştir. İlk Koruma Amaçlı İmar Planı ise 1982 yılında yapılmıştır. Günümüzde ise 2003 yılında yürürlüğe giren yeni Koruma Amaçlı İmar Planı kullanılmaktadır (Anonim, 2006).

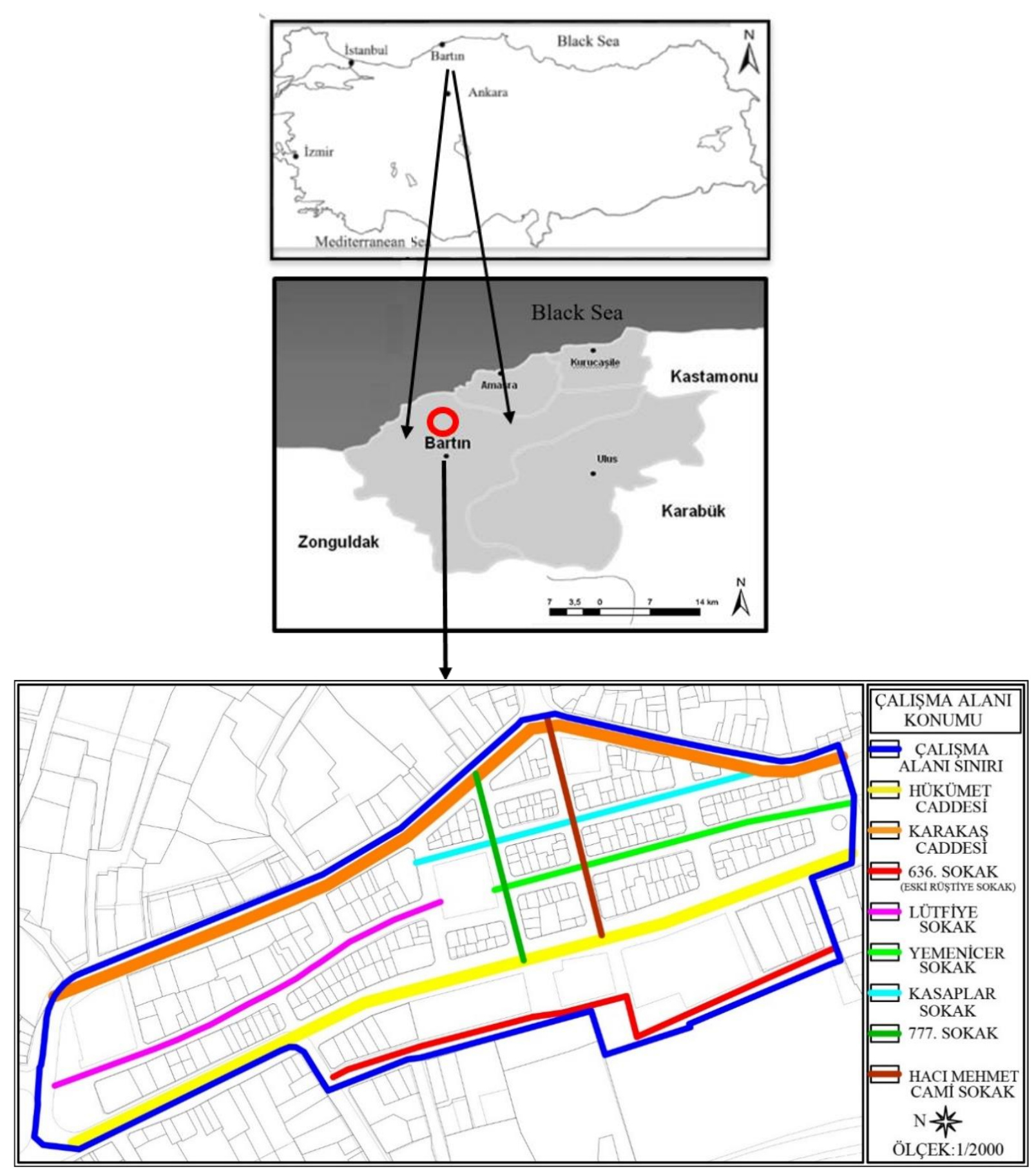

Şekil 1. Araştırma alanının Bartın Kentindeki konumu 
Bartın'daki geleneksel sivil mimari örnekleri ise Osmanlı döneminin mimarisini, estetik anlayışını, yaşama biçimini, kültürünü yansıtmaktadır. Art Nouveau ve Barok sanatlarını yansitan Bartın Evleri genellikle iki ya da üç katlı ve "Daraba" denilen ağaç çitlerle çevrili bahçe içindedir. Katlar ahşap-karkas olup, zemin katları taştır. Evlere iki kanatlı bir kapıdan "Gulluk" bölümünden girilmektedir. Giriş bölümü ile bahçelerdeki yürüme alanları kayrak taşlarla kaplıdır. Her bahçede taştan yapılmış bir kuyu bulunmaktadır. Evler çok pencerelidir ve özgün giyotin pencereler olup, sadece merdiven ve cumbaları aydınlatanlar yuvarlak formludur (Anonim, 2007). Cephelerde simetrik bir görüntü hakimdir, giriş cephelerinde, üst katlarda ve ortada "Cumba" mevcuttur. Çatılar alaturka kiremit ile örtülüdür (Aşcığlu, 2001). 2000 yılında Tarihi Kentler Birliği'ne üye olan Bartın kentinde tarihî dokuyu korumak ve yaşatmak amacıyla tarihî yapıların röleve ve restorasyonları, sokak sağlıklaştırma çalışmaları yapılmış ve yapılmaya devam etmektedir. Samanc1oğlu Sokak Sağlıklaştırma Projesi 2004 yılında yapılmış, uygulama ise 2009 yılında gerçekleştirilmiştir. Ayrıca, Bartın'da 250 adet tescilli bina yer almaktadır.

Bunun yanı sira Bartın Kentsel Sit Alanında yer alan tarihi yapılar ile yeni yapılacak yapılarda, sokaklarda ve kentsel donatı elemanlarında kullanılacak olan malzemelere ilişkin bilgiler koruma amaçlı imar plan raporlarında yer almaktadır. 2003 yılında hazırlanan BartınKentsel Sit Alanı, Etkileme Geçiş Alanı Korunacak Sokaklar Koruma Amaçlı İmar Planı Plan Koşulları'nda; "genel koşullar madde 7'de, koruma sokaklarında yaya yollarında Arnavut kaldırımı ya da benzeri parke taş ve taş türevleri (kilitli taş) malzeme kullanılacaktır. Madde 8'de, teknik alt yapı tesisatı toprak altından geçirilecek, aydınlatma direkleri alanın karakterine uygun malzeme ve üslupta seçilecektir. Madde 14'de, Koruma Amaçlı İmar Planı sınırları içerisinde reklam, tabela ve panoları yola çıkma şeklinde asılamaz. $\mathrm{Bu}$ tabelalar bina cephelerine ve maksimum boyutları $0.50 \mathrm{~m}^{2}$ geçmeyecek şekilde asılacaktır." denilmektedir. Sit Alanı İçerisindeki Tescilsiz Mevcut ve Yeni Yapılacak Yapıların Koşulları da madde 9'da yer almakladır. Ayrıca "çatılar alaturka kiremitli çatı yapılacak, anten ve benzeri elemanlar bahçe içinde ortak sistemle çözülecektir." şeklinde ifadeler yer almakladır (Anonim, 2003).

\subsection{Araştırma Alanına İlişskin Bulgular}

$\mathrm{Bu}$ bölümde araştırma alanının mevcut durumu analiz edilmiş ve alana özgü haritalar oluşturulmuştur. $\mathrm{Bu}$ kapsamda yapıların kullanım amaçları, tescilli yapı, anıtsal kültür varlığı gibi korunmas1 gerekli yap1 kapsamında olup olmadığı, kat yükseklikleri, araç ve yaya sirkülasyon sistemi, yeşil alan varlığı, nirengi/odak noktaları, kent mobilyalarının yeterli olup olmadığ 1 gibi konularda analizler yapılmıştır. $\mathrm{Bu}$ bağlamda araştırma alanının ana arterini oluşturan Hükümet Caddesi ve diğer sokaklar üzerinde özel mülkiyetteki ticari yapıların yoğun olarak yer aldığ 1 saptanmıştır. Kullanım tipleri eczane, lokanta, kafe, banka, market, kuyumcu, tekstil ürünleri satış birimleri olarak özetlenebilir. Ayrıca alan içinde Kent Müzesi ve 4 adet cami bulunmaktadır (Şekil 2).

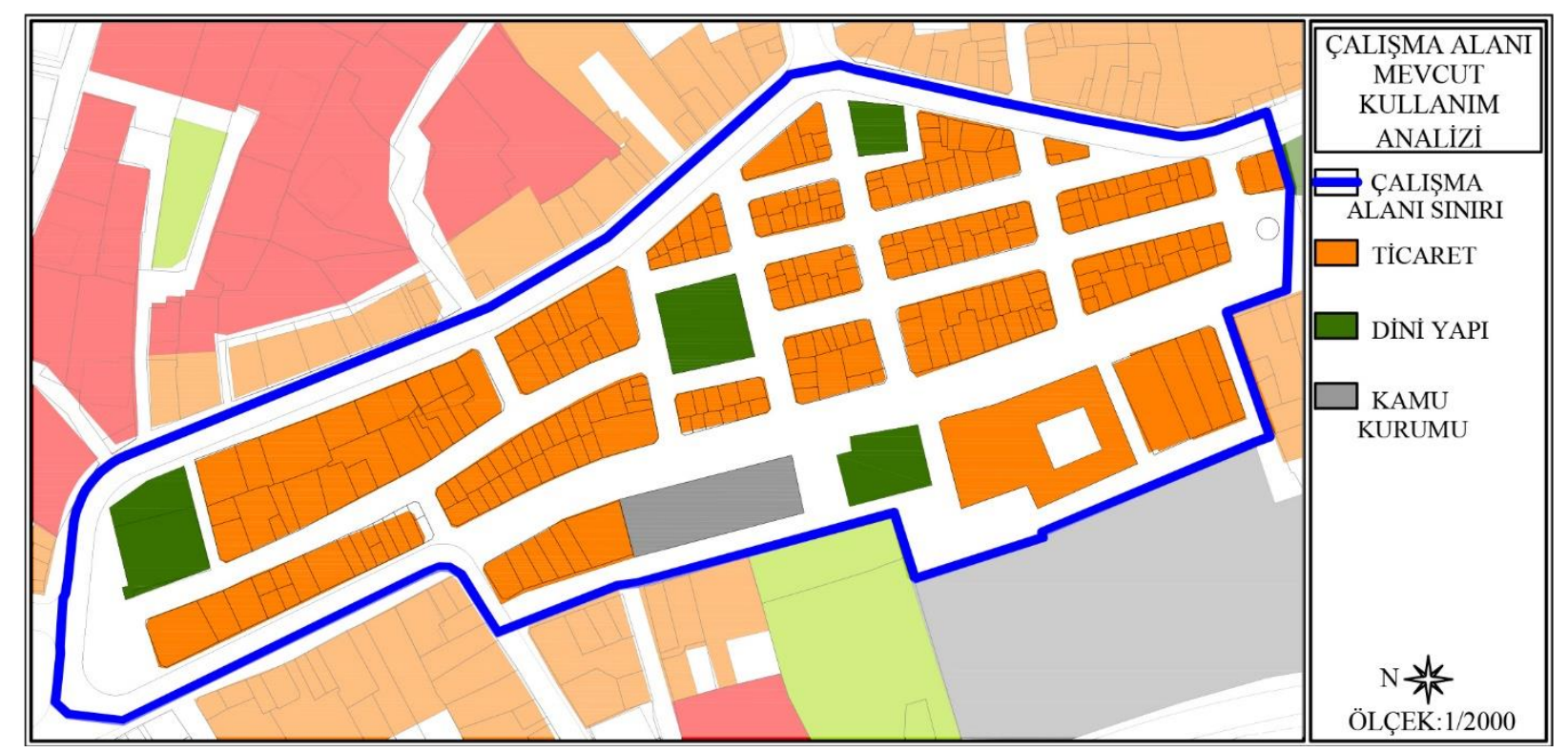

Şekil 2. Araştırma alanındaki mevcut kullanımlar 
Ayrıca, araştırma alanında geleneksel sivil mimari örnekleri yoğun olarak yer almaktadır ve birçoğu ticari amaçlı kullanılmaktadır. Bunlar kırtasiye, lokanta, banka, kafe gibi kullanımlardır. Tarihi yapılar bitişik nizamda inşa edilmiştir. Sokakların düşey sınırlarını bu binaların dış cepheleri ve sokağa açılan kapıları oluşturmaktadır. Hükümet caddesi ve diğer sokaklardaki yapılar direkt sokağa açılmaktadır. Alandaki tescilli yapılar ise dağınık bir yerleșim düzeni sergilemektedir. Taşhan'ın yanı sıra anıtsal kültür varlığı olarak, Arap Cami, İbrahim Paşa Cami, Hacı Mehmet
Cami, Halil Bey Cami bulunmaktadır. Geleneksel özelliğini koruyan 1. Grup yapılar ise Karakaş Caddesi üzerinde yer almaktadır (Şekil 3)

İnsan ölçeğinde tasarlanmış olan alanda 2,3,4 katlı yapılar bulunmaktadır ve binaların alt katları ticari amaçla, üst katları ise büro, ticaret, depo amaçlı kullanılmaktadır. Binaların çoğu 2 katlıdır. Yeni yapılan binalar betonarme olup, diğerleri geleneksel mimari yapı tekniğine uygun olarak inşa edilmiştir. Alandaki binalarda bahçe bulunmamaktadır (Şekil 4).

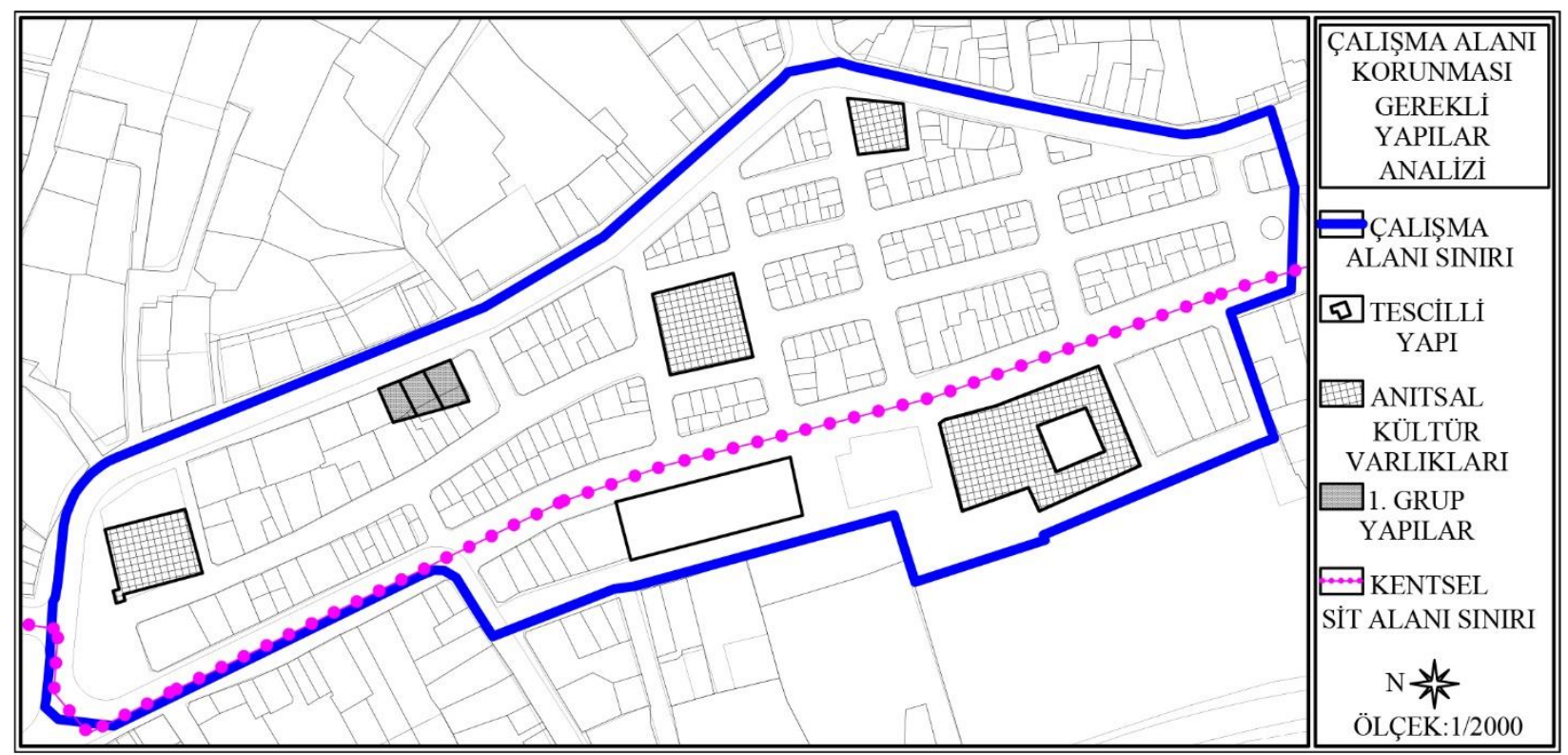

Şekil 3. Araştırma alanındaki tescilli yapılar

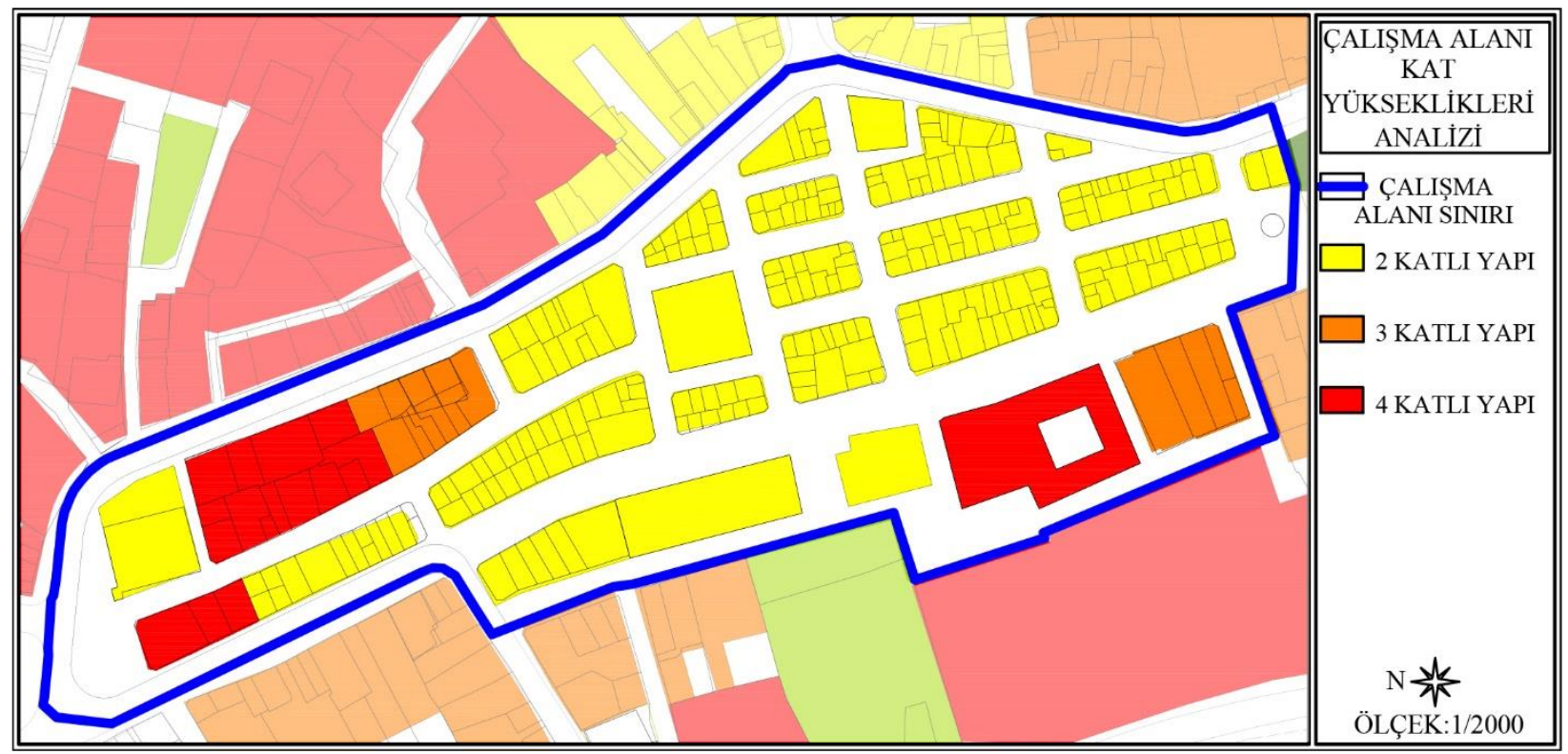

Şekil 4. Araştırma alanındaki yapıların kat yükseklikleri

Kat yüksekliğinin yanı sıra sokak genişlikleri de insan ölçeğinde planlanmıştır. Cadde ve sokaklar birbirine dar ve kısa ara sokaklarla bağlanmış durumdadır. Hükümet caddesi Bartın kent merkezinin en önemli akslarından biridir. 2002 yılında caddenin bir bölümü araç trafiğine 
kapatılmıştır. Yukarı Çarşı Sokak, Hamam Sokak, 636. Sokak ile Karakaş Caddesinin sınırladığı alan yaya bölgesi olarak düzenlenmiştir. Hükümet Caddesi ve diğer sokaklar sadece günün belli saatlerinde araç girişine açıtır. Araçlar ticari işletmeler için alana girebilmektedir. Hamamönü Sokak ise Koruma Amaçlı İmar Planına göre korunacak sokak niteliğindedir. Alanda özellikle 636. sokakta kafe ve çay bahçeleri yoğun olarak bulunmaktadır (Şekli 5).

Tarihi yapılar ve anitlar hem tarihi bir belge niteliğindedir hem de kent peyzajına estetik açıdan katkıda bulunurken zaman içinde de kentsel imge/odak noktası olarak değer kazanmaktadır. Örneğin Ayasofya ve Süleymaniye Cami İstanbul'un önemli odak noktalarındandır (Kuban, 2000). Bartın kent merkezinde de Şadırvan, Su Terazisi, Taşhan, Kent Müzesi (Eski Belediye Binası), Arap Cami önemli odak noktaları arasında yer almaktadır (Şekli 5). Bu öğeler fiziksel olarak yüksekte olmayıp, kullanım farklılıkları ile ön plana çıkmaktadır. Kentte yaşayanlar bu odak noktalarını yön ve yer bulmada tarif edici öge olarak kullanmaktadır.

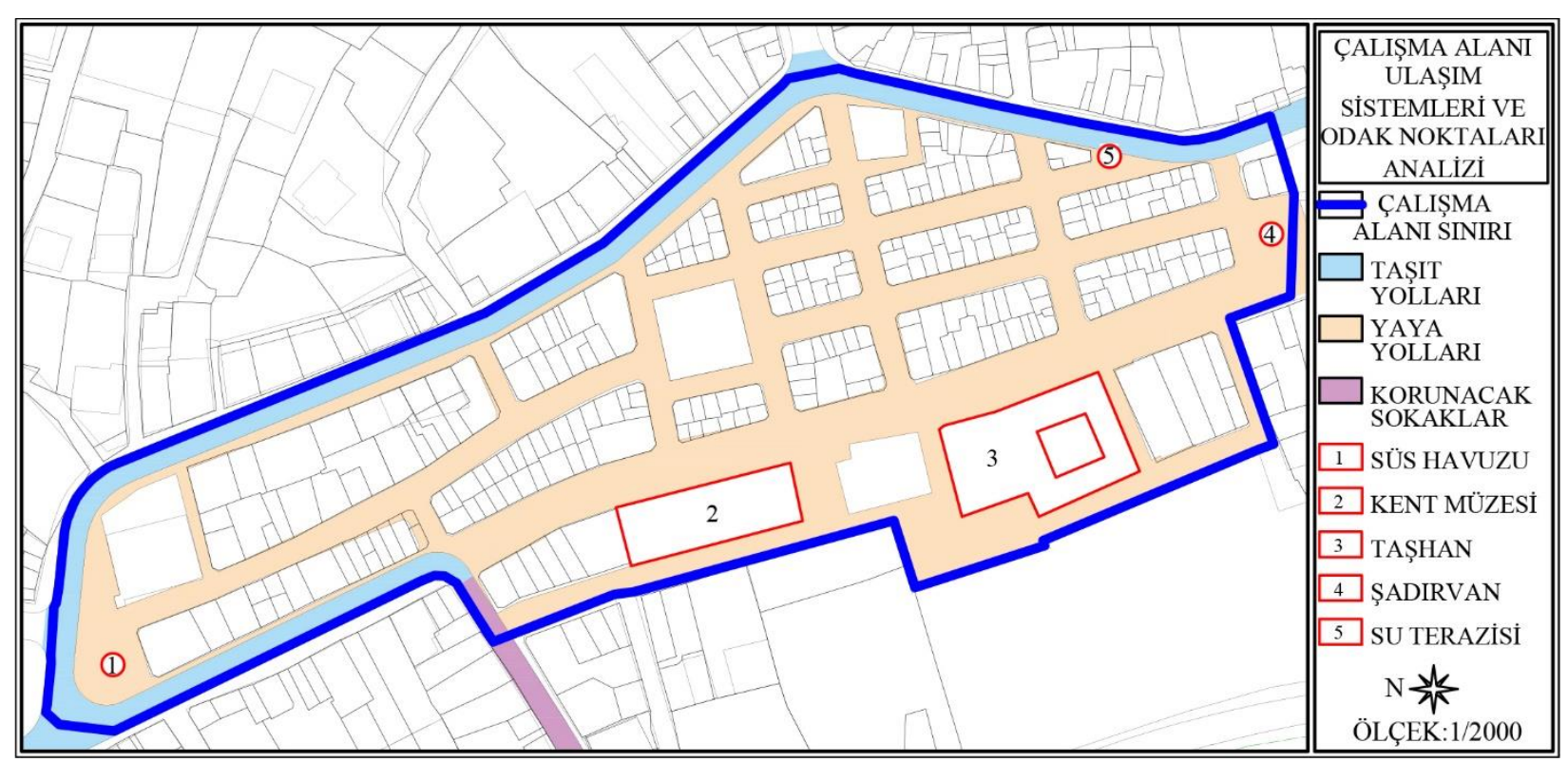

Şekil 5. Araştırma alanındaki ulaşım sistemi ve odak noktaları

Bunun yanı sıra alanda yapılan gözlem ve incelemeler sonucunda tarihi yapıların fonksiyon değiştirdiği, çağdaş yaşam konforu özelliklerini taşımadığı, yıprandığı, eskidiği saptanmıştır. $\mathrm{Bu}$ durumlara bağlı olarak yapılan tadilat ve cephe giydirmeleri de farklı sorunlara neden olmaktadır. Örneğin, geleneksel sivil mimari yap1 cephelerinde tadilat sonrası renk ve doku, uyumu olmamakta, pencereler farklı büyüklükte olmakta ve mimari tipolojiyi yansıtmamaktadır. Ticari amaçlı kullanılan yapıların giriş katlarındaki tüm cepheler cam vitrin olarak kullanılmaktadır. $\mathrm{Bu}$ nedenle binalar tarihi yap1 özelliği taşımamaktadır. Ayrıca, tarihi yapıların yanında yeni yapılmış modern binalar yer almaktadır. Ticari işletmeler dükkanlarının ön bölümlerini ürünlerini sergilemek için kullandığ 1 için yolun kullanım alanı daralmakta, görsel kirliliğe ve sokak dokusunda uyumsuzluğa neden olmaktadır.
Araştırma alanındaki zemin döşemelerinde farklı şekillerdeki beton parke taşlar ve desenler kullanılmıştır. Özellikle Hükümet Caddesinde kullanılan desen hem form hem de ölçek bakımında tarihi doku ile uyum göstermemektedir. Yine alan içinde yol ağaçlaması ve bahçeli konut bulunmamaktadır. Oysa, güvenli bir yaya ağ 1 , düzenli yol ağaçlaması, düşük trafik hızı ile konforlu ve gölge mekanlar oluşturabilir (Çelikyay ve Öztaş, 2018). Alanda sadece Arap Cami önünde iki adet Aesculus hippocastanum (At Kestanesi) yer almaktadır. Tüm Cadde ve sokaklarda yüksek aydınlatma ve çöp kutusu bulunmaktadır. Yukarı Çarşı Caddesi ve Hükümet Caddesinde çiçek kasaları kullanılarak yeşil doku elde edilmeye çalışılmıştır. Bu kentsel donatı elemanları tarihi doku ile malzeme, form, ölçek ve renk açısından 
uyum sağlamamaktadır. Çelikyay ve Karayılmazlar (2016) tarafindan da Hükümet Caddesindeki kentsel donatı elemanlarının kent kimliği ve bulunduğu çevreyle uyum sağlamadığ estetik düzeyinin az olduğu ifade edilmiştir.

Alan analizleri sırasında alana ilişkin olumlu gelişmelerde saptanmıştır. Araç trafiğine açık olan Yukarı Çarşı Caddesi ve Karakaş Caddesinde yaya güvenliği için sınır elemanı yer almaktadır. Yukarı Çarşı Caddesi, Hükümet Caddesinin ve Karakaş Caddesinin iki tarafında kaldırım ve görme engelliler için duyumsanabilir (hissedilebilir) yüzeyler bulunmaktadır. Hükümet Caddesinde plastik obje olarak simitçi, bakırcı ve ağda satan kişi heykelleri yer almaktadır. Bu heykeller hem kent kimliğini yansıtmakta hem de ölçek bakımından alan ile uyum içindedir.

\section{Sonuç ve Öneriler}

Araştırma alanında çoğunlukla tarihi sivil mimari örnekleri ile anıtsal kültür varlıkları yer almaktadır. Kent merkezinin ana aksı durumunda olan Hükümet Caddesi alışveriş ve kültürel aktivitelerin yapıldığ 1 mekan niteliğindedir. Fakat alanda modern binalar, kısmen tadilat yapılmış ve fonksiyon değiştirmiş tarihi binalar bulunduğu için alan kent kimliğini kısmen yansıtmaktadır. Ceplerdeki farklı renk, form ve büyüklükteki tabelalar görsel kirliliğe neden olmaktadır. Zemin kaplamada kullanılan desen tarihi doku ile uyum sağlamamaktadır. Kentsel donatı elemanları birbiri ve kentsel kimlik ile uyum içinde değildir. Ticari işletmelerin yaya yolunun bir bölümünde ürünlerini sergilemeleri kullanım alanını daraltmış ve görsel algıyı zorlaştırmaktadır.

Araştırma alanında olan Hükümet Caddesi ve etkileşim içinde olduğu tarihi kent merkezinde zaman içinde yapılarda eskime-yıpranma ve işlevsel dönüşümler, kentsel mobilyalarda ve zemin döşemelerinde yenileme çalışmaları yapılmış ve yapılmaya devam etmektedir. Fakat tarihi doku genelinde yapılan tadilat, yenileme vb. uygulamaların birçoğu "Bartın-Kentsel Sit Alanı, Etkileme Geçiş Alanı Korunacak Sokaklar Koruma Amaçlı İmar Planı Plan Koşullarının” tamamına uyum sağlamamaktadır. Alandaki sokakların korunacak sokak olmaması mevcuttaki uygulamaların gerçekleşmesine imkan sağlamıştır. Oysa tarihi merkez kentsel sit alanı içinde olduğu için plan koşullarına uygun uygulamaların yerine getirilmesi gerekmektedir. Böylece tarihi dokunun korunması, yaşam kalitesinin artırılması, sosyo kültürel yapının korunması, farkındalığın artması, görsel kirliliğin azalması mümkün olabilecektir.
Özellikle cephelerde birden fazla sayıda bulunan klima, çanak anten, yola çıkan reklam tabelaları hem görsel kirliliğe hem de tarihi dokunun algılanmamasina neden olmaktadır.

$\mathrm{Bu}$ nedenle araştırma alanı için kentsel peyzaj odaklı sokak sağlıklaştırma plan ve projelerine yönelik ölçütlerin belirlenmesi amaçlanmıştır. Araştırma alanında mülkiyet bakımından hem sokak, cadde gibi kamusal mekanlar hem de ticari işletme, konut gibi özel mekanlar yer almaktadır. Yapısal anlamdaki ölçütleri önerirken "Korunması Gerekli Sokakları Sağlıklaştırma Projesi Teknik Şartnamesindeki" ilkeler dikkate alınmıştır. İşlevsel, başarılı bir şekilde tasarlanmış kamusal alanlar oluşturmak için de Madden (2001) tarafindan belirlenen kolay erişim, kullanım imkanı, konfor, sosyalleşme gibi temel ölçütlerin yanı sıra koruma kullanma dengesini gözetmek, sosyo ekonomik gelişim, engelsiz ulaşım gibi parametreler belirleyici olmuştur.

$\mathrm{Bu}$ bağlamda kentsel peyzaj odaklı korunması gerekli sokak sağlıklaştırma plan ve projelerinde planlama, tasarım, uygulama bağlamında aşağıdaki ölçütler önerilmiştir.

- Sokak sağliklaştırma plan ve projeleri 2863 sayılı Kültür ve Tabiat Varlıklarını Koruma Kanunu, ilgili yasa ve yönetmelikler ile alanda geçerli olan koruma imar planlarına uygun olarak hazırlanmal1,

- Koruma kullanma dengesi gözetilerek alan kullanım kararları verilmeli,

- Alanın iklimsel özellikleri dikkate alınmalı,

- Alanın sosyal, ekonomik, ekolojik, estetik ve fiziksel özellikleri dikkate alınmalı,

- Kent siluetini koruyacak plan ve tasarmm kararları verilmeli,

- Yerel halk öncelikli olmak üzere alan kullanıcılarının istek ve talepleri belirlenerek ihtiyaç listeleri oluşturulmal,

- Doğal ve kültürel kimlik bileşenleri saptanıp, bunlar1 yansitan mekansal tasarımlar yapılmali,

- Engelsiz kullanımlar için çocuk, yaşlı, dezavantajlı gruplar için gerekli önlemler alınmali,

- Kentsel donatı elemanları (bank, aydınlatma elemanı, çiçek kasası, vb.), reklam panosu, tabelaların malzeme, doku, renk ve ölçü olarak tarihi doku ile uyumu sağlanmal,

- Zemin döşeme ve cephe kaplamalarında tarihi dokuya uygun malzeme seçilmeli,

- Kesintiye uğramayacak yaya ve araç sirkülasyon sistemi oluşturulmal,

- Alt ve üst yap1 sistemlerinin yeterli miktarda ve etkin kullanımda olması sağlanmalı, 
- Sokak dokusunda turistik kullanımlar için sergi salonu, el sanatları atölyeleri, turistlerin dinlenme ve fotoğraf çekim alanı gibi kullanımlara yer verilmeli,

- Bitkisel tasarımlarda öncelikle tarihi dokuda tercih edilen bitkiler saptanmalı ve tasarımlarda bu bitkilere yer verilmeli,

- Bununla birlikte bitkisel düzenlemelerde mekanın estetik algısını artıracak yaprak, dal ve çiçek özelliği ile ön plana çıkan dekoratif bitkiler tercih edilmeli,

- Tasarımlarda kamu yararı gözetilmeli,

- Konusunda uzman birçok disiplinin bir arada olduğu kadro ile plan ve projeler hazırlanmalı,

- Uzun/orta/kisa hedeflerde uygulanabilecek tasarımlar yapılmalı,

- Uygulama surecinde izleme, denetleme ve bu süreçte elde edilen veriler doğrultusunda yeniden değerlendirme yapılmalı,

- Elektrik hattı yer altına alınmalı, cephelerdeki anten, klima gibi objelerin ortak kullanımlar ile sayıs1 azaltılmal,,

- Hasarli olan tarihi yapiların restorasyon, restitüsyon ve rölöve projeleri yapılmalı,

- Yapı sahipleri cephe ve balkonlarının onarımı, bakımı gibi konularda "en güzel cephe" yarışmaları ile kent estetiğine katkı sunmaları konusunda teşvik edilmeli,

- Yönlendirme levhaları, reklam tabelaları kent estetiği ve kent silueti dikkate alınarak uygun yerlerde bulunmali,

- Malzeme temini ve işçilik bakından uygulanabilir tasarımlar yapılmalı,

- Açık ve yeşil alanlara yönelik tasarımlarda kültürel kimliği koruyacak ve kimlik ögelerini bu mekanlara yansitacak projeler üretilmeli,

- Açık ve yeşil alanlarda peyzaj bakım ve onarım işleri periyodik olarak yapılmalı,

- Kent estetiği üzerinde fiziksel çevre, biyolojik çevre ve sosyo kültürel çevre etkili olmaktadır. $\mathrm{Bu}$ çevrelerde kullanılan boya ve çevreyi kaplayan diğer malzemelerin rengi de kişiler üzerinde etkili olmaktadır (Ojo ve Kayode, 2006). Bu nedenle renklerin kişiler üzerindeki psikolojik etkileri göz önüne alınarak renk seçimi yapılmalı,

- Tarihi doku ve kent kimliği ile uyum gösterecek simit, kestane, misır gibi seyyar satış birimleri tasarlanmal,

- Yerel yönetim, kanaat önderleri, özel sektör, üniversite ve yerel halk birlikte çalışabilmeli,

- Halkın projeyi sahiplenmesi için güveni kazanılmalıdır.

Sonuç olarak, araştırmada sokak sağlıklaştırma plan ve projelerinde ilgili yasa ve yönetmeliklerle uyumlu, yerel halkın benimsediği, kent kimliğini yansıtan, alanında uzman birden fazla meslek disiplinin bir arada olduğu ekip tarafindan kısa, orta, uzun vadede uygulamaya geçirilecek plan ve projeleri hazırlamaya yönelik ölçütler önerilmiştir. Gerçekleşecek olan koruma ile sadece fiziksel koruma değil, sosyo kültürel ve ekonomik korumada mümkün olabilecektir

\section{Kaynaklar}

Ahunbay, Z., 2004. Tarihi Çevre Koruma ve Restorasyon, Üçüncü baskı, Yapı Yayınları, İstanbul, 212s.

Altınörs Çırak, A., 2017. Plan Kararlarının Uygulanmasında Bir Konsensüs Oluşturma ve İşbirliği Deneyimi: İzmir Kemeraltı Sokak Sağlıklaştırma Çalışmalarının Öyküsü. Planlama, 27(3): 286-302.

Anonim, 2003. Bartın-Kentsel Sit Alanı, Etkileme Geçiş Alanı Korunacak Sokaklar Koruma Amaçlı İmar Planı Plan Koşulları. Bartın Belediyesi, İmar ve Şehircilik Müdürlüğü, Bartın.

Anonim, 2006. Bartın Nazım İmar Planı Araştırma Raporu. Bartın Belediyesi 01.05.2006 Tarih 86 Sayılı Meclis Kararı, Bartın.

Anonim, 2007. Kültür Kenti Bartın'1 Keşfedin, Mitolojiden Gezginlere. Kültür ve Turizm Envanteri, Bartın İl Kültür ve Turizm Müdürlüğü Yayını, Ankara, 180s.

Anonim, 2008. Bartın 2023 stratejik amaçlar ve il gelişme planı, Bartın Valiliği İl Planlama ve Koordinasyon Müdürlüğü, Bartın.

Anonim, 2009. Tarihi Çevre Koruma, Tarihi Çevre Koruma: Yaklaşımlar, Uygulamalar, Dosya14.1, TMMOB Mimarlar Odası Ankara Şubesi.

Anonim, 2014. Yerel Yönetimler Kentleşme ve Demokrasi, Sempozyum, 23-24 Ocak 2004, TMMOB Mimarlar Odası, İstanbul.

Aşcıoğlu, E., 2001. Bartın. Bartın Ticaret ve Sanayi Odası Yayını, Ankara.

Bartın Belediyesi, 2014. Bartın belediyesi 2015-2019 dönemi stratejik planı, Eylül 2014, ss.179, Bartın.

Çelik, D. ve M. E. Yazgan, 2007. Kentsel Peyzaj Tasarımı Kapsamında Tarihi Çevre Korumaya Yönelik Yasa ve Yönetmeliklerin İrdelenmesi. ZKÜ Bartın Orman Fakültesi Dergisi. 9 (11): 110. 
Çelik, D., Açıksöz, S., 2008. Tarihi Kentlerde Kent Estetiği Kaygısı: Bartın Örneği Bartın Orman Fakültesi Dergisi, 10(14): 57-65.

Çelikyay, H. S., \& Karayılmazlar, S., 2016. Bartın Kent Merkezindeki Kamusal Alanların Kentsel Ergonomi ve Kent Kimliği Açısından İrdelenmesi. Bartın Orman Fakültesi Dergisi, 18(2): 224-238.

Çelikyay, H. S., \& Öztaş, R. G., 2018. LEED ND yeşil sertifika sistemleri bağlamında ekolojik mahalle tasarım1. Presented at the International Eurasian Conference on Science, Engineering and Technology (Eurasian Sci En Tech 2018), Ankara.

Çelimli, M. A., 2016. Divriği Kent Dokusundaki Geleneksel Konut Mimarisinin İncelenmesi ve Örnek Sokak Sağlıklaştırması Üzerine Bir Değerlendirme (Yüksek Lisans Tezi), Erciyes Üniversitesi Fen Bilimleri Enstitüsü Mimarlık Anabilim Dalı, Kayseri.

Çetin R. Z., Sönmez İ. S., 2014. Tarihi Kent Merkezlerinde Yeniden Canlandırma Stratejileri. Ege Mimarlık, 18-21.

Elnokaly A., Elseragy A., 2013. Sustainable Heritage Development: Learning from Urban Conservation of Heritage Projects in Non Western Contexts. European Journal of Sustainable Development, 2: 31-54.

Kiper, P., 2008. Küreselleşme Sürecinde Kentlerin Tarihsel-Kültürel Değerlerin Korunması: Türkiye- Bodrum Örneği, Sosyal Araştırmalar Vakfi Yayını.

Kuban, D. 2000. Tarihi Çevre Korumanın Mimarlık Boyutu Kuram ve Uygulama, Birinci Bask1, Yap1 Endüstri Merkezi (YEM) Yayınları, İstanbul, 207s.

Madden, K., 2001. How to turn a place around: A handbook for creating successful public spaces. New York.

Madran, E., Özgönül, N., 2005. Kültürel ve Doğal Değerlerin Korunması. 1. Baskı, Yalçın Matbaacılık, Ankara.
Ojo B., Kayode F., 2006. The Role of Colour in Environmental Beautification and Urban Aesthetics: The Nigerian Example. Indoor Built Environment, 15(6): 543-550.

Özyaba, M., vd. 1999. Kentsel Alanların Planlanmas1 ve Tasarımı. Karadeniz Teknik Üniversitesi Mühendislik- Mimarlık Fakültesi, ders notları, no:54, s.424-467, Trabzon.

Rodwell, D., 2007. Conservation and Sustainability in Historic Cities. Malden, Mass. Blackwell Publ. $262 \mathrm{~s}$.

Smith, B. 2002. Tarihi Kentlerin Korunmasında Yöntemler. Türkiye'de Tarihî Kent Dokularının Korunması ve Geleceğe Taşınması Sempozyumu, TC Kültür Bakanlığı Kültür ve Tabiat Varlıklarını Koruma Genel Müdürlüğü, 8-11 Şubat 2002 - Kemer, Antalya, s.125-129.

UNESCO (United Nations Educational, Scientifc and Cultural Organization), 2013. New Life for Historic Cities, Paris.

URL-1, http://www.icomos.org.tr/?Sayfa=Tuzukler1\&di l=tr. 15 Aralık 2018.

URL-2, http://www.resmigazete.gov.tr/eskiler/2005/06/2 0050618.htm. 05 Aralık 2018.

URL-3, http://www.odunpazari.bel.tr/haber-1390odunpazarinda_hemsehrilerimizin_daha_saglam _saglikli_ve_estetik_evlerde_yasamalarini_istiy oruz\#PopupGoster[popup]/0/. 28 Nisan 2019

URL-4, http://artibirproje.com/Sayfa.aspx?Pid=20. 22 Mart 2019.

URL-5, https://biruni.tuik.gov.tr/medas/?kn=95\&locale= tr. 25 Mayıs 2019.

Ünver, H., 2017. Sokak Sağlıklaştırmanın Tanımsal Olarak İrdelenmesi. Düzce Üniversitesi Bilim ve Teknoloji Dergisi, 5: 96-106. 